\title{
Professional training and autonomy of nursing teachers in the qualification of higher education in nursing
}

\author{
Formação e autonomia profissional dos docentes de enfermagem na qualificação do ensino superior em enfermagem
}

Formación y autonomía profesional de docentes de enfermería en la titulación de educación superior en enfermería

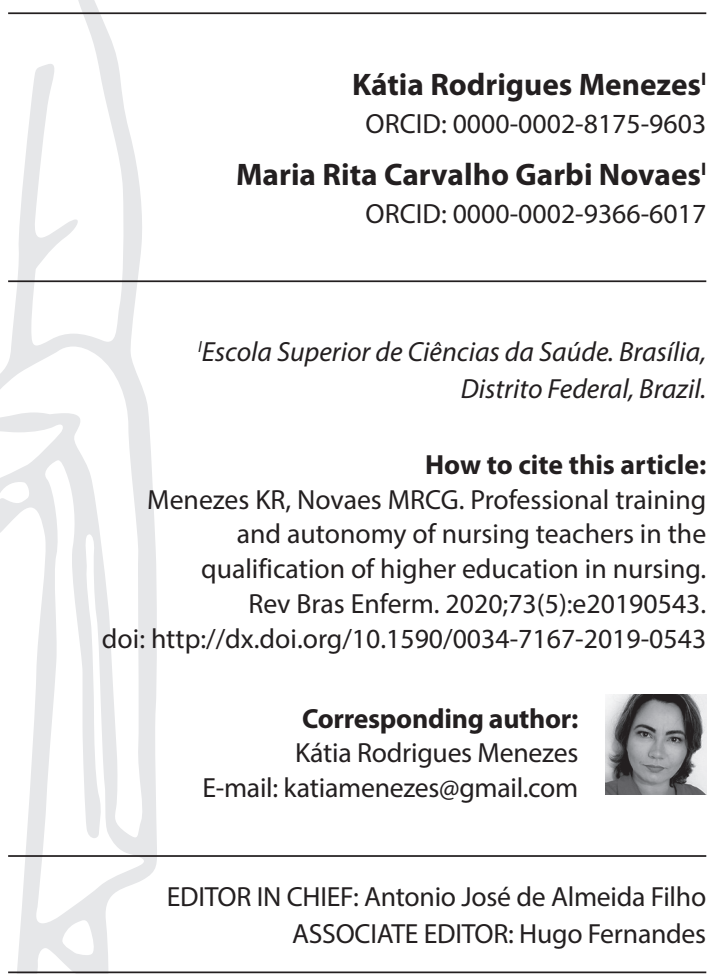

Submission: 06-18-2019
Approval: 10-20-2019

\section{ABSTRACT}

Objectives: to identify the aspects related to professional training and autonomy of undergraduate nursing teachers of a public institution in Brasilia, Federal District, in order to contribute to the course management and qualification. Methods: mixed method study conducted with 77 teachers. A semi-structured questionnaire was applied, where quantitative items were evaluated through the Student's $T$ and ANOVA $(p<0.05 \%)$ parametric tests. The qualitative part underwent content analysis with use of the IRAMUTEQ software and descending hierarchical classification. Results: the training of professionals was focused mostly (67.5\%) on their initial area of expertise, and their mean values in autonomy-related factors were low and moderate. Two categories emerged in the qualitative analysis: "Identifying teacher autonomy" and "Applying teacher autonomy". Conclusions: understanding the meaning and degree of autonomy perceived by teachers can foster the reflection on the praxis and enhance their performance.

Descriptors: Professional Autonomy; Faculty, Nursing; Education, Professional; Education, Nursing, Baccalaureate; Nursing.

\section{RESUMO}

Objetivos: identificar aspectos relativos à formação profissional e à autonomia dos docentes de graduação em Enfermagem de uma instituição pública de Brasília, Distrito Federal, de forma a contribuir na gestão e na qualificação do curso. Métodos: estudo misto, realizado com 77 docentes. Aplicou-se questionário semiestruturado, onde os itens quantitativos foram avaliados por testes paramétricos: Teste t-student e ANOVA $(p<0,05 \%)$. A parte qualitativa passou por análise de conteúdo com subsídio do software IRAMUTEQ, e foi empregada a Classificação Hierárquica Descendente. Resultados: com formação voltada majoritariamente $(67,5 \%)$ à sua área de atuação inicial, os profissionais expressaram médias baixas e moderadas nos fatores relacionados à autonomia. Na análise qualitativa emergiram duas categorias: "Identificando a autonomia docente" e "Aplicando a autonomia docente". Conclusões: entender o significado e o grau de autonomia percebido pelo docente pode fomentar a reflexão da práxis e potencializar sua atuação.

Descritores: Autonomia Profissional; Docentes de Enfermagem; Educação Superior; Educação em Enfermagem; Enfermagem.

\section{RESUMEN}

Objetivos: identificar aspectos relacionados con la formación profesional y la autonomía de los docentes universitarios de enfermería de una institución pública en Brasilia, Distrito Federal, para contribuir a la gestión y calificación del curso. Métodos: investigación de método mixto realizada con 77 docentes. Se aplicó un cuestionario semiestructurado, donde los ítems cuantitativos se evaluaron mediante las pruebas paramétricas T de Student y ANOVA $(p<0.05 \%)$. La parte cualitativa se sometió a análisis de contenido con el uso del software IRAMUTEQ y clasificación jerárquica descendente. Resultados: con la formación enfocada principalmente (67.5\%) en su área inicial de experiencia, los profesionales expresaron promedios bajos y moderados en factores relacionados con la autonomía. En el análisis cualitativo surgieron dos categorías: "Identificar la autonomía del docente" y "Aplicar la autonomía del docente". Conclusiones: comprender el significado y el grado de autonomía percibido por los docentes puede fomentar la reflexión de la praxis y mejorar su desempeño.

Descriptores: Autonomía Profesional; Docentes de Enfermería; Educación Superior; Educación en Enfermería; Enfermería. 


\section{INTRODUCTION}

The role of nursing teachers and their education has been the target of research ${ }^{(1-2)}$ and is directly related to nurses' competence profile and their ability to provide comprehensive care to the population, including technical and ethical aspects, prevention, promotion and recovery of health. In higher education, teachers usually hold an undergraduate degree and often lack proper pedagogical preparation for teaching ${ }^{(3-5)}$. The education legislation states that teachers should prepare for higher education through postgraduate courses to minimize this gap, and at least one third of the faculty must have stricto sensu training (master's or PhD) ${ }^{(1,6)}$. However, postgraduate education has traditionally trained experts and researchers rather than teachers, which hinders professionals' identity process ${ }^{(6)}$.

The construction of nursing teacher's professional identity is a socialization process ${ }^{(2)}$ based on continuous construction and gathering together the professional's technical experience and the exercise of the teaching role ${ }^{(7)}$. According to studies, teacher autonomy can be a motivating element for better professional performance in nursing teaching ${ }^{(2,6)}$.

Teachers' professional autonomy is a complex discussion, and its understanding is influenced by several points of view ${ }^{(8)}$. One of the interpretations brings the idea of freedom, independence or individualism ${ }^{(9)}$, and according to this conception, autonomy is concentrated in the classroom and requires that teachers are free from external influences ${ }^{(9)}$. Thus, teachers are considered experts, have their practice depoliticized and are more concerned with the effective and efficient mastery of techniques that aim to achieve previous goals without evaluating other social sectors ${ }^{(8)}$.

When conceiving teacher autonomy without considering the sectors that influence teaching and seeing it as noncompliance with norms, professionals give it a simplistic and misleading meaning. This solipsistic view of teacher autonomy places teachers islanded in the classroom, and devalues the commitment to the community and the moral obligation of the profession, which are linked to the emotional dimension of teaching and learning process agents ${ }^{(8)}$. This isolation weakens the collective dimension of the profession and undermines the class achievements beyond the classroom. It also denies actors' possibility of acting with interdependent collaboration by fear of interference with their autonomy ${ }^{(9-10)}$.

Teacher autonomy is not an innate capacity of professionals, but a constant exercise in the performance of their personal and professional life ${ }^{(8)}$. Teaching activities are separated into two axes: the decision level and the decision content ${ }^{(11)}$. The decision level encompasses policies, rules and methods for its implementation, while the decision content concerns pedagogical, administrative and organizational issues. Pedagogical and organizational principles must be considered in teacher autonomy ${ }^{(11)}$.

Such multidimensionality promotes the idea of different degrees of autonomous professional in certain dimensions and refutes the thought of an unlimited exercise of teacher autonomy ${ }^{(9,11-13)}$. Teacher autonomy should be reflexive and given its historicalsocial construction, it bears an intimate relationship with historical, cultural and social changes suffered over time ${ }^{(8-9)}$. Contrary to the solipsist conception, the contemporary view of teacher autonomy reveals a negotiated construction between teachers' conscious and reflective desires and institutional and social norms and rules $^{(14-15)}$, because autonomy is based on experience, decisions and conflicts lived collectively $y^{(8,16)}$.

Given the above, in this study, teacher autonomy was conceived as an ability to act before the reflection on the praxis that considers its interfering factors and mediates the relationships between subjects thereby promoting conscious and responsible decision making. Knowing the meaning of autonomy for the nursing faculty and how they refer exercising it can contribute for the improvement of work processes. Therefore, this investigation provides support for studies on a little explored subject in the nursing literature and improves the quality of teaching professionals' performance, because it stimulates the reflection on the teaching practice and contributes to the appreciation of nurses' training.

The guiding questions of this study were: What does autonomy mean for nursing teachers? To what extent do nursing teachers feel autonomous in the exercise of teaching?

\section{OBJECTIVES}

To identify the aspects related to professional training and the autonomy of undergraduate nursing teachers of a public institution located in Brasilia, Federal District (FD), in order to contribute to the management and qualification of the course.

\section{METHODS}

\section{Ethical aspects}

This study complied with national and international standards of ethics in research involving human beings and was approved by the Research Ethics Committee of the Health Sciences Teaching and Research Foundation of the Federal District.

\section{Type, period and location of study}

Descriptive, cross-sectional, mixed method study. The mixed method design involves two steps, namely the quantitative and qualitative. Quantitative and qualitative data were collected concurrently and compared to determine convergences, differences and combinations between the following parts: the quantitative (QUAN), first and priority; and the qualitative (QUAL), second and lower weighted. These two approaches were interconnected by data triangulation. Analysis of data collected in the "QUAN" step guided the data collection of the "QUAL" step ${ }^{(17)}$. Data were collected from October to November 2017.

The location chosen for the study was a public Higher Education Institution (HEl), Undergraduate Nursing Course, in Brasília, FD. This course was created in 2008 and uses Active Teaching and Learning Methodologies in two Educational Programs: (1) Problem Based Learning (PBL) in Tutorial Dynamics (TD) from $1^{\text {st }}$ to $3^{\text {rd }}$ year; (2) Problematization Methodology (PM), applied from $1^{\text {st }}$ to $3^{\text {rd }}$ year in the Nursing Professional Skills Program and in the Compulsory Curricular Internship Program that finalizes the course curricula in the $4^{\text {th }}$ year ${ }^{(18)}$.

In the beginning of the study, the contact number/email of teachers and managers of the Higher Education Institution was asked to the course coordinator. Later, the study objectives were presented to them. 


\section{Population: inclusion and exclusion criteria}

The selection of participants was performed intentionally. The sample consisted of 77 teachers, who performed the functions of class management and teaching. In order to avoid bias, the total sample was calculated by decreasing the participation of a teacher who is the author of this study. The sampling calculation was performed through EPI INFOTM VERSION 7.2.0.1 software, available online at the following address: $<$ http://www.cdc.gov/ epiinfo/index.html>. In order to reach the $99.9 \%$ confidence level, the sample had an expected frequency of $50 \%$, margin of error of $5 \%$ and the result was an expected sample of 81 teachers. As some teachers were on leave of absence during the data collection period, 77 teachers participated in the study, which represented a $99 \%$ confidence level.

Inclusion criteria were being a teacher of the nursing course at the Higher Education Institution for at least six months. Absent teachers during the data collection period (vacation or on leave) or those working in the institution for less than six months were excluded.

\section{Study protocol}

Data were collected through a semi-structured instrument divided into three parts: the characterization of professional training and performance, the Teacher Professional Autonomy Scale (Portuguese acronym: EAPP) and the individual interview. This last part (interview) included a Job Satisfaction Questionnaire for Teachers, which will be presented later.

The first part, "QUAN", characterized the technical and pedagogical training of professionals and the following variables: type of graduation, time since graduation, highest postgraduate level and area, courses in the area of education and teacher training. In this part, was also identified the participant performance in teaching: teaching experience, time of work in the HEl and performance in the nursing course, considering management or teaching functions.

In the second part, following the "QUAN" stage, participants answered objective questions measured by the EAPP, which is a scale with dimensions related to teacher autonomy ${ }^{(19)}$. The use of the scale in the present study was authorized in writing by one of the authors. It is a Likert scale with six levels of measurement and enough data to achieve the objective proposed; 1 represents no autonomy and 6 total autonomy. The domains are: Autonomy in the formation of classes; Autonomy in subject teaching; Autonomy in professional training; Autonomy in teaching and assessment of school performance; and Autonomy in curriculum change and development.

In addition to measuring teacher autonomy, it was necessary to understand its meaning for participants. Thus, in the third part of the instrument, teachers were asked an open question so they could express their opinion "For you, what is the meaning of autonomy in the exercise of teaching?". Each record was transcribed, and participants were assigned the letter $\mathrm{T}$ (teacher) and a sequential number from 1 to 77 to guarantee their anonymity.

Answers to the open questions were read several times in order to complement all data provided. After the transcription, additional information from the field diary was included in parentheses. For data categorization, was chosen the IRAMUTEC software (Interface de R pour les Analyses Multidimensionnelles de Textes et de Questionnaires) version 0.7 alpha 2. For this study, the peculiarities of nursing teaching were used as pre-categories. The coding was performed by two researchers separately for greater reliability.

\section{Analysis of results and statistics}

In the "QUAN" part, the Statistical Package for the Social Sciences (SPSS) version 21.0 was used for descriptive analysis of data. For inferential analyzes, were applied parametric tests. Firstly, the normality of data was checked by the Kolmogorov-Smirnov test. The Student's T test was used to compare the mean of two groups in two-category variables (sex, type of degree, type of specialization, experience in $\mathrm{HEl}$, work unit and function performed). The one-way ANOVA was used to compare the means between three groups in three-category variables (total experience and age range). All analyzes were performed considering a significance level of $5 \%$.

Data of the "QUAL" step were categorized with use of the software. Then, came the analysis of information using the content analysis technique according to Bardin ${ }^{(20)}$ and the steps of pre-analysis, material exploration or coding and treatment of results - inference and interpretation. The Descending Hierarchical Classification (DHC) was used, in which "text segments are classified according to their respective vocabularies"(21) and subsequently, are established categories and classes. Fifty text segments were observed in the corpus, with occurrence of 1829 words in 474 different forms and word usage of $84.75 \%(n=1,550)$.

At the end, results were triangulated and were performed "QUAN" and "QUAL" analyzes of the data set.

\section{RESULTS}

\section{Characterization of training and professional performance}

The study included 77 teachers with ages ranging from 27 to 59 years old, average of 41.5 years old ( $\mathrm{SD}=8.6$ years). All teachers had postgraduate degrees; 52 (67.5\%) had postgraduate studies related to their initial training area and 25 teachers (32.5\%) reported having postgraduate courses focused on education, of which 23 (92\%) were specialization courses and two (8\%) were master's in education. As specific training for pedagogical practice, 29 teachers $(37.6 \%)$ reported having a pedagogy degree and two $(2.6 \%)$ completed short-term courses in the area of education. In addition, upon joining the HEl, all teachers took a short-term teaching course in active teaching and learning methodologies (Table 1).

Teachers had a mean experience of eight years in higher education ( $S D=6.2$ years). The working time in the HEl varied between one and 10 years, with an average of 4.6 years (SD $=2.5$ years). Sixty-eight teachers (88.3\%) worked directly in teaching, while nine (11.7\%) worked in the management of the Nursing Undergraduate Course. Teachers have a weekly workload of 40 hours, out of which 20 hours dedicated to teaching (according to 
the rules of the $\mathrm{HEI}$ ) and the other 20 hours dedicated to clinical care in the National Health System of DF. However, seven teachers (9.09\%) worked full time at the HEl, and of these, six professionals (85.7\%) performed managerial duties and one (14.3\%) worked in teaching. Sixty-nine teachers (89.6\%) reported feeling adapted to the use of active methodologies and to the teaching and learning methods adopted by the institution (PM and PBL), three (3.9\%) did not feel adapted to these methods and five (6.5\%) did not answer this question.

Table 1 - Sociodemographic, educational and professional data of Nursing undergraduate teachers ( $\mathrm{n}=77$ ), Brasília, Federal District, Brazil, 2017

\begin{tabular}{|c|c|c|}
\hline Variables & $\mathbf{N}$ & $\%$ \\
\hline \multicolumn{3}{|l|}{ Sex } \\
\hline Male & 17 & 22.1 \\
\hline Female & 60 & 77.9 \\
\hline \multicolumn{3}{|l|}{ Age range $^{+}$} \\
\hline$<35$ & 16 & 20.8 \\
\hline $35-44$ & 27 & 35.1 \\
\hline$>45$ & 25 & 32.5 \\
\hline Not available & 9 & 11.7 \\
\hline \multicolumn{3}{|l|}{ Training area } \\
\hline Nursing & 75 & 97.4 \\
\hline Psychology & 1 & 1.3 \\
\hline Physiotherapy & 1 & 1.3 \\
\hline \multicolumn{3}{|l|}{ Postgraduate studies } \\
\hline Master's/PhD (Lato sensu) & 37 & 48.1 \\
\hline Specialization (Stricto sensu) & 40 & 51.9 \\
\hline \multicolumn{3}{|l|}{ Total time of teaching experience ${ }^{\dagger}$} \\
\hline Up to 3 & 21 & 27.3 \\
\hline $4-9$ & 27 & 35.1 \\
\hline$<10$ & 28 & 36.4 \\
\hline Not available & 1 & 1.3 \\
\hline \multicolumn{3}{|l|}{ Time of experience ${ }^{\dagger}$} \\
\hline Up to 4 & 39 & 50.6 \\
\hline$>5$ & 38 & 49.4 \\
\hline \multicolumn{3}{|c|}{ Educational Program where teacher works } \\
\hline TD & 21 & 27.3 \\
\hline NPS and CCI & 43 & 55.8 \\
\hline Not available & 13 & 16.9 \\
\hline \multicolumn{3}{|l|}{ Role performed } \\
\hline Teacher & 68 & 88.3 \\
\hline Management & 9 & 11.7 \\
\hline Total & 77 & 100.0 \\
\hline
\end{tabular}

According to Table 2, teachers expressed moderate and low mean values regarding autonomy. The factor "Formation of classes" presented the lowest average (1.95; SD=0.76), while"Professional training" had the highest mean value (3.59; $S D=1.40)$.

\section{Teacher Professional Autonomy Scale}

In the second stage "QUAN", in the factor "Autonomy in the formation of classes", the item with the highest mean value (2.52; $\mathrm{SD}=1.64$ ) was "I have autonomy to decide on the definition of class formation criteria (heterogeneous or homogeneous classes)". Within the "Autonomy in subject teaching" factor, the items that stood out with the highest mean values were"I am free to choose enriching themes for my students drawn from existing official programs" (3.93; SD=1.46) and "I have the freedom to choose enriching themes for my students drawn from programs designed by the school itself" (3.92; SD=1.51).

Regarding the factor "Autonomy in professional training", teachers had higher mean values in the items "I can choose the location of my professional training" (2.80; SD=1.71) and "I can choose the time when I want to do my professional training" (3.72; $\mathrm{SD}=1.70)$. The items "I have the power to set limits on students" behavior" and "I have autonomy regarding the work to be done in the classroom" stood out in the factor "Autonomy in teaching and assessment of school performance" with mean values of $4.16(S D=1.33)$ and $3.77(S D=1.38)$, respectively. The last factor of the EAPP addresses "Autonomy in curriculum change and development" and higher mean values were found in items "I have autonomy to define curriculum objectives" $(2.74 ; S D=1.49)$ and "I have autonomy to eliminate or add themes to the official curriculum" (2.29; SD=1.39).

Parametric statistical tests were performed to check the relationship between EAPP factors and some variables such as teachers' age, sex, postgraduate degree, teaching time, among others presented in Table 3.

\section{Qualitative analysis: descending hierarchical classification and content analysis}

The secondary "QUAL" part, in the $1^{\text {st }}$ partition, according to the descending hierarchical classification, the corpus was divided into two categories (Figure 1). The first was "Identifying teacher autonomy", represented by Class 3 (subcategory"Definition of autonomy") and corresponded to $33.3 \%$ of Elementary Context Units (ECU). During the $2^{\text {nd }}$ partition, the second category, called "Applying teacher autonomy", was divided into two subcategories that gave rise to Class 1 (subcategory "Autonomy in work processes") and Class 2 (subcategory"Autonomy in strategies") which corresponded to $24.2 \%$ and $42.4 \%$ of the ECU, respectively. 
Table 3 - Relationship between mean values of Teacher Professional Autonomy Scale factors and variables, Brasília, Federal District, Brazil, 2017

\begin{tabular}{|c|c|c|c|c|c|c|c|c|c|c|}
\hline \multirow{3}{*}{ Variables } & \multicolumn{10}{|c|}{ Factors of Teacher Professional Autonomy Scale } \\
\hline & \multicolumn{2}{|c|}{ Formation of classes } & \multicolumn{2}{|c|}{ Subject teaching } & \multicolumn{2}{|c|}{$\begin{array}{l}\text { Professional } \\
\text { training }\end{array}$} & \multicolumn{2}{|c|}{$\begin{array}{c}\text { Teaching and } \\
\text { assessment of } \\
\text { school performance }\end{array}$} & \multicolumn{2}{|c|}{$\begin{array}{l}\text { Curriculum } \\
\text { change and } \\
\text { development }\end{array}$} \\
\hline & $\mathbf{M}$ & $p$ value & $\mathbf{M}$ & $p$ value & M & $p$ value & M & $p$ value & $\mathbf{M}$ & $p$ value \\
\hline \multicolumn{11}{|l|}{ Sex } \\
\hline $\begin{array}{l}\text { Male } \\
\text { Female }\end{array}$ & $\begin{array}{l}2.28 \\
1.85\end{array}$ & $0.037^{*}$ & $\begin{array}{l}3.47 \\
3.43\end{array}$ & $0.917^{*}$ & $\begin{array}{l}3.52 \\
3.61\end{array}$ & $0.818^{*}$ & $\begin{array}{l}3.27 \\
2.97\end{array}$ & $0.258^{*}$ & $\begin{array}{l}2.15 \\
2.20\end{array}$ & $0.848^{*}$ \\
\hline \multicolumn{11}{|l|}{$\mathrm{Age}^{\dagger}$} \\
\hline$<35$ & 1.84 & & 3.38 & & 3.96 & & 3.05 & & 2.61 & \\
\hline $35-44$ & 1.79 & $0.057^{* *}$ & 3.36 & $0.813^{* *}$ & 3.67 & $0.321^{* *}$ & 2.85 & $0.618^{* *}$ & 2.00 & $0.184^{* *}$ \\
\hline$>45$ & 2.26 & & 3.57 & & 3.30 & & 3.10 & & 2.10 & \\
\hline \multicolumn{11}{|l|}{ Training area } \\
\hline $\begin{array}{l}\text { Nursing } \\
\text { Othe }\end{array}$ & $\begin{array}{l}1.95 \\
1.90\end{array}$ & $0.932^{*}$ & $\begin{array}{l}3.46 \\
2.83\end{array}$ & $0.469^{*}$ & $\begin{array}{l}3.61 \\
2.90\end{array}$ & $0.482^{*}$ & $\begin{array}{l}3.04 \\
3.00\end{array}$ & $0.960^{*}$ & $\begin{array}{l}2.21 \\
1.50\end{array}$ & $0.359^{*}$ \\
\hline \multicolumn{11}{|l|}{ Postgraduate studies } \\
\hline $\begin{array}{l}\text { Master's/PhD (Lato Sensu) } \\
\text { Specialization(Stricto Sensu) }\end{array}$ & $\begin{array}{l}1.77 \\
2.11\end{array}$ & $0.047^{*}$ & $\begin{array}{l}3.22 \\
3.64\end{array}$ & $0.123^{*}$ & $\begin{array}{l}3.51 \\
3.67\end{array}$ & $0.622^{*}$ & $\begin{array}{l}2.95 \\
3.11\end{array}$ & $0.466^{*}$ & $\begin{array}{l}2.07 \\
2.31\end{array}$ & $0.333^{*}$ \\
\hline \multicolumn{11}{|l|}{ Time of teaching experience ${ }^{\dagger}$} \\
\hline Up to 3 & 1.75 & & 3.29 & & 3.47 & & 3.02 & & 2.33 & \\
\hline $4-9$ & 1.77 & $0.047^{* *}$ & 3.40 & $0.790^{* *}$ & 3.51 & $0.745^{* *}$ & 2.94 & $0.873^{* *}$ & 1.96 & $0.439^{* *}$ \\
\hline$>10$ & 2.19 & & 3.53 & & 3.75 & & 3.07 & & 2.25 & \\
\hline \multicolumn{11}{|l|}{ Time of experience in $\mathrm{HEI}^{\dagger}$} \\
\hline $\begin{array}{l}<5 \\
>5\end{array}$ & $\begin{array}{l}1.74 \\
2.16\end{array}$ & $0.015^{*}$ & $\begin{array}{l}3.43 \\
3.46\end{array}$ & $0.921^{*}$ & $\begin{array}{l}3.68 \\
3.51\end{array}$ & $0.606^{*}$ & $\begin{array}{l}3.15 \\
2.92\end{array}$ & $0.304^{*}$ & $\begin{array}{l}2.28 \\
2.11\end{array}$ & $0.490^{*}$ \\
\hline \multicolumn{11}{|l|}{ Role performed } \\
\hline $\begin{array}{l}\text { Teaching } \\
\text { Management }\end{array}$ & $\begin{array}{l}1.80 \\
3.07\end{array}$ & $<0.001^{*}$ & $\begin{array}{l}3.27 \\
4.70\end{array}$ & $<0.001^{*}$ & $\begin{array}{l}3.47 \\
4.49\end{array}$ & $0.041^{*}$ & $\begin{array}{l}2.91 \\
3.94\end{array}$ & $0.002^{*}$ & $\begin{array}{l}2.10 \\
2.92\end{array}$ & $0.030^{*}$ \\
\hline \multicolumn{11}{|c|}{ Educational Program where teacher works } \\
\hline $\begin{array}{l}\text { TD } \\
\text { NPS or } \mathrm{CCl}\end{array}$ & $\begin{array}{l}2.03 \\
1.67\end{array}$ & $0.035^{*}$ & $\begin{array}{l}3.33 \\
3.29\end{array}$ & $0.898^{*}$ & $\begin{array}{l}3.91 \\
3.23\end{array}$ & $0.041^{*}$ & $\begin{array}{l}2.90 \\
2.96\end{array}$ & $0.063^{*}$ & $\begin{array}{l}2.19 \\
2.08\end{array}$ & $0.692^{*}$ \\
\hline
\end{tabular}

The presentation of words with strong associative forces was confirmed by results of the chi-square test $\left(X^{2}\right)$ as shown in Figure 1. The category "Identifying teacher autonomy" brought the subcategory "Definition of autonomy", where professionals used words as rule, mine, own, way and others in order to present a concept of autonomy, as the following excerpts point out:

[Autonomy] is the freedom to work in teaching without or with the least interference of coordination in the work developed with the student. (T21)

To be able to perform the teaching activity without interference from other components. (T23)

Autonomy is the ability to develop what has been proposed by the school in consistency with my principles and educational objectives, that is, an own way of teaching, by giving space for the student with responsibility. (T40)

Being free to act as a teacher by respecting the procedural rules. (T61)

Autonomy: being able to act in a context that is not intensely standardized and monitored. (T67)

The subcategories "Autonomy in work processes"and "Autonomy in strategies" are closely related and part of the "Applying teacher autonomy" category because their content is linked to the forms of expressing teacher autonomy. The words'pedagogical','possibility' and 'process' appeared as central elements of the "Autonomy in work processes" subcategory, thereby demonstrating the relationship made by teachers between the meaning of autonomy and their pedagogical work process, as follows:

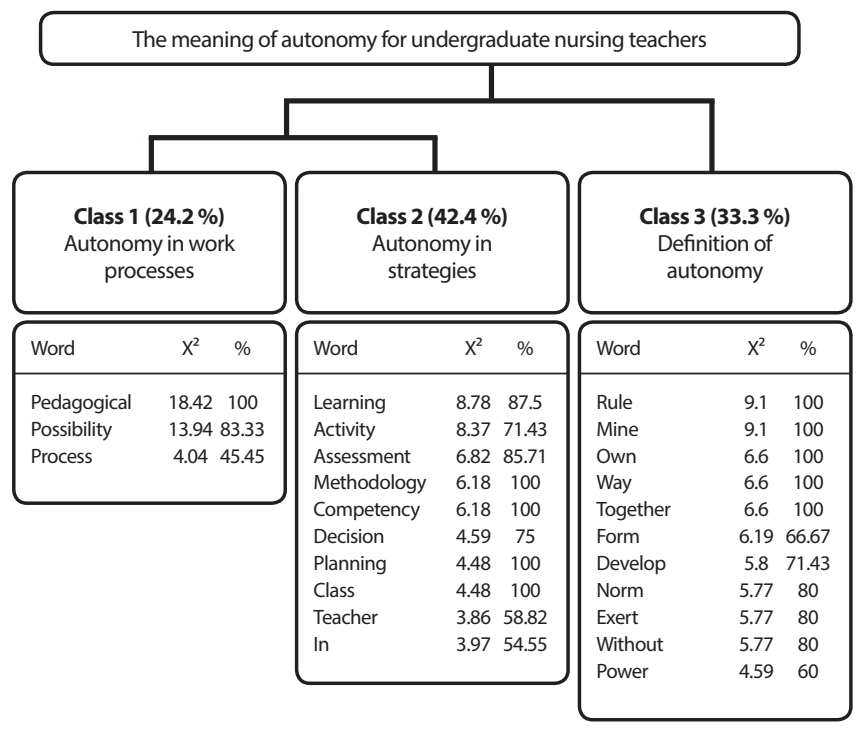

Figure 1 - The meaning of autonomy for teachers: dendrogram of classes provided by the IRAMUTEQ software, Brasília, Federal District, Brazil, 2017 
Autonomy is the freedom to make necessary modifications for improvement of the teaching-learning process. (T17)

Autonomy is the possibility of having freedom to build or rebuild the organization of their work process in teaching. (T64)

The premise of using innovation and changes in the teachinglearning process. (T49)

The subcategory "Autonomy in strategies" accounted for $42.4 \%$ of ECUs and was linked to the strategies used by teachers during pedagogical activities. Words such as learning, activity, methodology, assessment, decision, planning and others appeared as central elements, as illustrated by the following fragments:

Autonomy means freedom to innovate in the methodology implementation and credibility in the decisions regarding the conduction of modules and assessments of students. (T46)

Autonomy in teaching is having space for speech and dialogue about daily teaching situations, it is creating new teaching and assessment strategies, it is performing activity planning in parallel with collective planning (including teaching topics). (T50)

It is the right to innovate, be creative and have independence to propose and execute a didactic activity with students and be respected by the faculty and students. Making rational decisions with freedom in teaching activities, preparation of tests and etc. (T74)

\section{DISCUSSION}

In this study, were identified aspects related to professional training that showed a predominance of female teachers. This is in agreement with a previous study ${ }^{(22)}$ and represents the phenomenon that happens in nursing as a whole. Another information in agreement with that same study ${ }^{(22)}$ was that teachers' median value indicative of a more experienced population, and the teaching experience is a divergence in relation to previous findings ${ }^{(22)}$.

The titling of teachers in the present study exceeded the legal determination ${ }^{(1,6)}$, since all were postgraduates, and $51.9 \%$ $(\mathrm{n}=40)$ had a master's degree or PhD. The studied group reinforces the tendency of teachers' interest in postgraduate courses in their areas of formation to the detriment of education, which corroborates with other studied authors ${ }^{(1,4,23)}$. Despite this fact, they are concerned about teacher training, since $37.6 \%(n=29)$ had an undergraduate degree focused on teaching and $32.5 \%$ $(n=25)$ had postgraduate studies in the area of education. This strengthens the idea that teaching requires specific knowledge not commonly addressed in regular undergraduate courses $\mathrm{s}^{(1,3-5)}$.

Autonomy in teaching is not discussed as an isolation or unrestricted freedom, but as construction and collaboration among the agents involved in the teaching and learning process ${ }^{(8-9)}$. However, teachers' speeches demonstrated those who conceptualize teacher autonomy as independence and performance of parallel actions or without influence of the collective.

From teachers' statements, the meaning of autonomy is clearly more linked to individual autonomy ${ }^{(12)}$, because they reported an individualistic interpretation of autonomy and more related to the application of teaching methods and strategies, with few references to the collective dimension of this construct.

Although most respondents expressed an individualistic conception of autonomy, some see it is a conscious and singularized capacity to act that mediates the relationship between institutional norms and the needs arising from the teaching and learning process. This posture strengthens the collective perspective and the construction of autonomy ${ }^{(8,12-13,15)}$ that occurs in everyday life through a critical-reflexive praxis mediated by dialogue with all agents involved in education processes ${ }^{(8,23)}$.

Based on most teachers' reports and on their moderate and low mean values in the EAPP (Table 2), it can be said that they consider their autonomy limited. Such a view is influenced by the appreciation of the individual autonomy dimension and requires consideration by the faculty, because individual autonomy is not opposed to institutional norms and teaching regulations ${ }^{(12)}$, but should lead professionals to reflect on their praxis and identify challenges in the relationships of actors in the institution, since autonomy is a process of construction ${ }^{(8,23)}$.

Another important aspect considered from teachers' speech and the mean values obtained in the EAPP was that although teachers work in a HEl where the Pedagogical Project adopts active methodologies, they do not value collegiate autonomy. In institutions that require teachers' collective work, individual autonomy loses its strength and teachers need to develop collegiate autonomy, that is, each teacher has an individual position and exerts influence on decision-making that is a collective process ${ }^{(12)}$.

By identifying aspects related to the autonomy of undergraduate nursing teachers, this study related the EAPP factors with some variables (Table 3 ) and there was no statistically significant difference regarding teachers' age. In relation to teachers' initial education, although nursing teachers had higher mean values than teachers who are not nurses, no statistically significant difference was found. Regarding sex, statistical significance was found only in the factor "Formation of classes", where men reported having greater autonomy than women, and their mean values were 2.28 and 1.85 , respectively ( $p$-value $=0.037$ ).

In the study sample, there was a significant difference in the "Formation of classes" factor when comparing the mean values of teachers who have a master's degree or PhD to those who have a specialization degree. In the referred factor, specialists obtained an average of 1.77 while those with a master's or PhD presented an average of 2.11 ( $p$-value $=0.047$ ).

Concerning professionals' experience in teaching, those with more experience had higher mean values in four factors of the EAPP, except in "Autonomy in curriculum change and development". However, there was a statistically significant difference only in the factor "Autonomy in the formation of classes" ( $p$-value $=0.047$ ). This factor also presented a statistically significant difference when relating the self-reported autonomy with the working time in the $\mathrm{HEl}$, which revealed a mean value of 1.74 among teachers working for less than five years, while teachers with a time equal to or above five years obtained a mean of 2.16 $(p$-value $=0.015)$. The literature on teacher identity issues in higher education indicates that professional experience contributes to higher security, improves teachers'identification with the profession and fosters their autonomy ${ }^{(2)}$. 
When analyzing the relationship between the type of methodology adopted by teachers in this study and the degree of autonomy, in general, teachers working in the TD Educational Program using PBL reported greater autonomy in most factors of the EAPP (except for the factor "Autonomy in teaching and assessment of school performance") compared to those working in the Nursing Professional Skills Program or the Compulsory Internship Program, where the problematization methodology is employed. However, there was statistical significance only in factors "Autonomy in the formation of classes" and "Autonomy in professional training". In the literature, were found no similar studies in undergraduate nursing courses.

Teachers' role in the course was the variable with the highest statistical relevance in all factors of the EAPP. Those with management roles obtained higher mean values than those with teaching roles. This reflects a natural and expected distinction due to the nature of positions ${ }^{(22)}$, since educational institutions in Brazil maintain a culture of control of work processes by managers. However, the investment of all actors in the teaching and learning process for teacher autonomy contributes greatly to the collaboration of the faculty ${ }^{(9)}$.

\section{Study limitations}

In the literature, there is a gap regarding the autonomy of nursing teachers. Studies with the theme of autonomy in nursing education revolve around student autonomy. When professional autonomy is addressed, studies bring the role of nurses in care and healthcare. For this reason, the analyzes in this study were based on teaching studies in general, which represented a limitation.
The scarce literature on the subject addressed here makes any comparison with other nursing courses impossible. However, the institution selected met the criteria, because its teachers exercised working hours in teaching and care activities, which allowed the evaluation of the objectives proposed in the study.

\section{Contributions to the area of nursing, health or public policy}

Reflections on teacher training and performance allow establishing strategies to enhance the practice of nursing teachers and increase the influence of these professionals on the training of new nurses.

\section{CONCLUSIONS}

This study highlighted the identification of aspects related to professional training and the autonomy of nursing teachers in a public HEl of the Federal District. The sociodemographic and labor characterization of teachers was identified, as well as the degree of professional autonomy perceived by these professionals in their daily work.

Despite the lack of studies on nursing teachers' autonomy in the literature, this discussion is important for adopting management strategies in HEls and new teachers' training. The construction of autonomy demands dialogical action of teachers with all actors in the teaching and learning process. In this sense, investments in nursing teachers' professional training corroborate the strengthening of professional identity and the development of teacher autonomy.

\section{REFERENCES}

1. Medeiros ESM, Prestes DRM, Pignata EKAA, Furtado RMS. Perfil do enfermeiro docente e sua percepção sobre a formação pedagógica. Recien. 2018;8(24):42-53. doi: 10.24276/rrecien2358-3088.2018.8.24.42-53

2. Fernandes CNS, Souza MCBM. [Teaching in higher educacion in nursing and identify construction: entry, career and permanence]. Rev Gaucha Enferm. 2017;38(1):e64495. doi: 10.1590/1983-1447.2017.01.64495

3. Lacerda CR. Saberes necessários à prática docente no ensino superior: olhares dos docentes dos cursos de bacharelado. Rev Docência Ens Sup [internet]. 2015 [cited 2019 Sept 15];5(2):79-100. Available from: https://periodicos.ufmg.br/index.php/rdes/article/view/2051/1367.

4. Vendrusculo C, Pozzebon A, Bender JW, Kloh D, Zocche DAA, Zanatta EA. Enfermeiro professor: limites e possibilidades da carreira docente. Rev Bras Cienc Saude. 2018;22(2):95-100. doi: 10.4034/RBCS.2018.22.02.01.

5. Treviso $\mathrm{P}$, Costa BEP. The perception of Professionals from the health área regarding their training as lecturers. Texto Contexto Enferm. 2017;26(1):e5020015. doi: 10.1590/0104-07072017005020015

6. Oliveira TP, Cruz GB. Inserção profissional docente no ensino superior. Arq Anal Pol Educat. 2017 24;25(78):1-23. doi: http://dx.doi.org/10.14507/ epaa.25.2887.

7. Lazzari DD, Martini JG, Busana JA. Teaching in higher education in nursing: na integrative literature review. Rev Gaucha Enferm. 2015;36(3):93-101. doi: 10.1590/1983-1447.2015.03.49670

8. Contreras J. Autonomia de docentes. 2. ed. São Paulo: Cortez; 2012.

9. Vangrieken K, Grosemans I, Dochy F, Kyndt E. Teacher autonomy and collaboration: a paradox? Conceptualizing and measuring teachers' autonomy and collaborative attitude. Teac Teach Educ. 2017;67:302-315. doi: 10.1016/j.tate.2017.06.021

10. Martins EBA. Formação de docentes e autonomia docente: algumas reflexões. Rev Eletr Fac Metodista Granbery [Internet]. 2010 [cited 2018 Nov 19];9:2-13. Available from: http://re.granbery.edu.br/artigos/Mzk4.pdf

11. Friedman IA. Teacher-perceived work autonomy: the concept and its measurement. Educ Psychol Meas. 1999;59(1):58-76. doi: $10.1177 / 0013164499591005$

12. Frostenson M. Three forms of professional autonomy: de professionalisation of teachers in a new light. Nord J Stud Educ Policy. 2015;2:2029. doi: 10.3402/nstep.v1.28464 
13. Wermke W, Rick SO, Salokangas M. Decision-making and control: perceived autonomy of teachers in Germany and Sweden. J Curriculum Stud. 2018;51(3):306-325. doi: 10.1080/00220272.2018.1482960

14. Selles SE, Andrade EP. Políticas curriculares e subalternização do trabalho docente. Educ Foco. 2016;21(1):39-64. doi: $10.22195 / 2447-5246 v 21 n 120162941$

15. Vasconcellos M, Vilela ML. Limites e possibilidades da formação inicial para o desenvolvimento de práticas docentes autônomas. Educ Rev. 2017;(63):157-172. doi: 10.1590/0104-4060.46646

16. Gebran RA, Trevizan Z. Social representations in the construction of professional identity and teachers' activity. Acta Sci Educ. 2018;40(2):e34534. doi: 10.4025/actascieduc.v40i2.34534

17. Creswell JW, Clark VLP. Pesquisa de métodos mistos. 2. ed. Porto Alegre: Penso; 2013.

18. Escola Superior em Ciências da Saúde (DF). Projeto pedagógico do curso de graduação em enfermagem da ESCS [Internet]. Brasília (DF): FEPECS; 2018 [cited 2018 Nov 19]. Available from: http://www.escs.edu.br/arquivos/PPC_2018.pdf

19. Veiga FH, Roque P, Guerra T M, Fernandes L, Antunes J. Escala de avaliação da autonomia profissional dos professores: elaboração e validação. Proceedings of the 7 Congresso Galaico-Português de Psicopedagogia; 2003 Sept 24-26; Universidade do Minho, Universidade da Corunha. Corunha: Universidade da Corunha; 2003. p. 1009-1017.

20. Bardin L. Análise de conteúdo. São Paulo: Edições 70; 2011.

21. Camargo BV, Justo AM. IRAMUTEQ: um software gratuito para análise de dados textuais. Temas Psicol. 2013;21(2):513-518. doi: 10.9788/ TP2013.2-16

22. Draganov PB, Sanna MC. Competências andragógicas dos docentes enfermeiros que atuam na graduação em enfermagem paulistana. Trab Educ Saude. 2016;14(1):155-182. doi: 10.1590/1981-7746-sip00098.

23. Freire P. Pedagogia da autonomia: saberes necessários à prática educativa. 47. ed. Rio de Janeiro: Paz e Terra; 2013. 